\title{
PORTRAYING PEACEFUL COEXISTENCE AND MUTUAL TOLERANCE BETWEEN SANTRI AND CHINESE COMMUNITY IN LASEM
}

\author{
MOHAMAD SOBIRIN ${ }^{1}$ \\ Universitas Islam Negeri Walisongo Semarang
}

Email: msobirin.sahal@gmail.com

\begin{abstract}
Coexistence and tolerance among the elite religious leaders in many cases seem not being considered as a problem, but at the grassroots level, the conflict often happened as an ironic phenomenon. This paper reveals and elaborates the socio-religious relations that existed between Santri and Chinese communities in Lasem-a small town located in the northern coastal part of the east end of the Central Java Province. The history recorded Lasem as one of the most important cities in Indonesia that bridged trading with China as early as the 14th century. It explains why Tionghoa villages (pecinan), as well as plenty of Konghucu's religious worshipping sites (klenteng), could be found in the town and also legacy sites as a place of religious worshipping of Konghucu. On the other hand, Muslims with a strong religious level largely grew in this town. With the qualitative approach, this research found that there are some factors contributing to build six models of coexistence, tolerance, and respect for the socio-religious diversities among the societies as the attitudes toward plural societies which brought into socio-harmony of Lasem. The analyzed data obtained through observation and interviews with various parties which is the object of this research, such as Islamic masters (kyai) and students (santri) at
\end{abstract}

Corresponding author; email: ${ }^{1}$ msobirin.sahal@gmail.com

ISSN 0852-7172 (p) 2461-064X (e)

(C) 2017 Walisongo: Jurnal Penelitian Sosial Keagamaan

http://journal.walisongo.ac.id/index.php/walisongo 
Islamic boarding school (pesantren) in Lasem, community and religious leaders of Chinese-Confucianism, and also documents that describe the historicity of Muslims and Chinese in Lasem.

Koeksistensi dan toleransi diantara kalangan elit pemuka agama dalam banyak kasus tampak tidak pernah ada permasalahan, namun pada kalangan grassroot tidak jarang konflik hadir sebagai fenomena yang ironis. Paper ini menampilkan hubungan sosial-keagamaan yang terjalin di antara komunitas santri dengan etnik Tionghoa beragama Konghucu di Lasem—kota kecil terletak di pantura bagian ujung timur provinsi Jawa Tengah. Sejarah mencatat bahwa Lasem adalah salah satu kota terpenting dalam peta pelayaran dan perdagangan China pada abad ke-16. Itulah mengapa di kota ini bisa ditemui tidak sedikit perkampungan orang Tioghoa dan juga situs-situs peninggalannya seperti tempat ibadah agama Konghucu. Disisi lain, di kota ini pula umat Muslim dengan tingkat keagamaan yang kuat tumbuh dan besar. Dengan pendekatan kualitatif, penelitian ini menemukan bahwa ada faktor yang turut membentuk enam model koeksistensi, toleransi, dan penghargaan terhadap perbedaan keyakinan diantara mereka. Pertama, integrasi sosial, kedua, asimilasi budaya, ketiga kooperasi bisnis, keempat selebrasi seremonial, kelima pelestarian budaya, dan keenam sinkritisme agama. Data yang dianalisis diperoleh melalui observasi dan interview dengan berbagai pihak yang merupakan objek penelitian ini, seperti kyai dan santri di empat pondok pesantren tertua di Lasem, tokoh dan masyarakat Tioghoa beragama Konghucu, dan juga dokumen-dokumen yang menerangkan historisitas Muslim dan Tionghoa di Lasem.

Keywords: Chinese; coexistence; Lasem, santri; tolerance.

\section{Introduction}

Indonesia is an archipelagic country characterized by cultural diversity. The diversity could be seen from the difference in language, ethnicity, and religious belief of the nation. On the one hand, this cultural diversity is an invaluable wealth of the 
nation, but on the other hand, it implies the potential for disintegration or split of the nation. Because, the cultural diversity is often used to be a tool to pull the trigger of conflict of ethnic, religion, and race.

Indonesia has been recorded tens or even hundreds of disputes and conflicts between ethnic and religious groups since its foundation. Yet only a few are in a large-scale. Conflicts on a smaller scale occur almost every year in various places across the country.

Towards the end of the New Order regime in 1997, largescale conflicts occurred in Indonesia. For example, the tragedy of shops destruction which owned by Chinese in various cities, such as Jakarta, Medan, Solo, and other cities in Indonesia. It was the conflict triggered by the ethnic issue. While religious conflicts could be found in Ambon.

Then, since 1998, which marked the end of the thirty-threeyear New Order regime under President Suharto, there has been a dramatic increase in ethnic conflict and violence in Indonesia. Jacques Bertrand argues that conflicts in Maluku, Kalimantan, Aceh, Papua, and East Timur were a result of the New Order's narrow and constraining reinterpretation of Indonesia's 'national model'. He showed how, at the end of the 1990s, this national model came under intense pressure at the prospect of institutional transformation, a reconfiguration of ethnic relations, and an increase in the role of Islam in Indonesia's political institutions. It was within the context of these challenges, that the very definition of the Indonesian nation and what it meant to be Indonesian came under scrutiny (Bertrand 2004).

While such ethnic and religious conflicts underwent in cities and towns in Indonesia, Lasem a small town located in the eastern end of the northern part of Central Java province showed the different view. It is a town inhabited by various ethnic groups 
(such as Javanese, Chinese, Arabian, and a few other small ethnic) and religions (like Islam, Confucianism, Christianity, Buddhism, Hinduism). That is why Lasem included as part of the regions in Indonesia which assumed as the potential for conflict, because of the plurality of its citizen. But until now, conflict is never visible in this "Small Chinese Town". Even when a variety of conflicts of ethnic and religion happened in many areas in Indonesia

The phenomenon indicates that Lasem's society which consisted of various ethnicities and religions live in a harmony and peace, no conflicts shown publicly. They build social interaction model that presents a peaceful coexistence and tolerance. Pluralism is not just doctrine, but it inherent in their lives. So far, Lasem often called a miniature of China town because there are temples and houses with Chinese typical architecture and the social cultural activities which are still dominated by the influence of Chinese culture. The big number of Chinese population or society in Lasem is not a barrier for them to assimilate and adapt into the local society and other ethnic. The fact, they could create works of unique culture. The question is how did the conflict not occur and can be eliminated within the plural society? how they build such tolerance and coexistence of social interaction in their social life? What forms of coexistence and tolerance embodied in their social life? And what factors have a role for the realization of the embodied coexistence and tolerance in its various forms among Lasem society? The answer to these questions is the scope of discussion that I put forward in this article.

\section{Chinese-Indigenous Conflict Theory in Indonesia}

According to Koentjaraningrat (1980) in terms of economic systems and socio-cultural systems, in general, Chinese ethnic seem to be separated from the community environment. Given 
this phenomenon, it is not surprising that the latent relationship between Indonesians ethnic and Chinese is described as fire in husks (Habib 2004).

The life of a seemingly stable and harmonious society is not a guarantee that in society there is no hostility and opposition. This fact can be found in the New Order society. In the new order, society looks harmonious, peaceful, and small levels of disagreement among members of society both in economic, ethnic, and religious dimensions. But behind the stability, harmony, and peace there is a great latent conflict. This is evidenced when the new order and power structure collapsed, latent conflicts in ethnic, religious, and separatist dimensions raged like mushrooms in the rainy season (Susan 2009)

Indigenous peoples are essentially a tolerant, eastern society. It is easy to accept other racial groups such as Arab, European, and other ethnic groups. But not so with Chinese ethnic groups, the tension for the tension and the confrontation either covertly or openly arose easily. The main problem arises because among many Chinese racial groups who still feel themselves more than indigenous groups. Therefore, Chinese groups from the Dutch era largely lived apart, kept their distance, and formed a dividing line with indigenous groups (Winarini and Badriyanto 2012)

According to Saleh, Kleden, and Bethan (1992), hostility and violence against an ethnic group, as happened in Chinese ethnic groups, have never been purely ethnic. It is true that ethnic differences, cultural differences, and racial differences can cause communication difficulties, but do not necessarily engender deep ethnic revenge, which leads to violence. Cultural differences and ethnic disposables are most likely to lead to misunderstandings. New ethnic relations cause hostility and violence if ethnic differences with one ethnic other are accompanied also by political or economic domination by one ethnic against another. 
Inter-ethnic conflicts, especially in Indonesia, are not merely ethnic issues but are more about economic-political power relations. Groups with political power can exchange their political power with economic benefits. Conversely, those with economic power can exchange their economic power to gain political protection and ease (Habib 2004).

The success of Chinese ethnic control of the national economic sector by many social science experts is always referred to as the trigger factor of social jealousy, the cause of which they become targets of rage. Riot events in a number of areas during the 1997 election season, or during the economic crisis and the ravages of basic foods that had made panic communities, developed into anti-Chinese riots (Hamzah 1998).

The contemporary Indonesian condition -by Vibhanshu Shekhar- he said in his book that the ethnic violence is as a result of the Islamic political movement and national development. In his article, he also stated that the issue of terrorism is also one of the crucial issues caused by the political and development of political movements that they feel are not fair. As a result, terror is directed towards groups seen as having economic power (Shekhar 2011)

\section{Lasem and the Plural Societies}

Plurality which is present in the society of Lasem includes a plurality of ethnic and religion. Currently, there are various ethnicities inhabit modern-day Lasem, such as Madura, Batak, Campa, and several others. Yet as for the majority of the population, it seems Javanese and Chinese still dominate the composition. While religion in which inherent in its everyday life consists of Islam, Confucianism, Christianity, Buddhism, and Hinduism. Majority of Javanese embraced Islam, while Chinese embraced Confucianism and Christianity, as well as Buddhism and Hin- 
duism. Nevertheless, this ethnic and religious difference was not being a reason for Lasem society to not behave tolerantly and apply pluralism in a variety of social interactions among them. Even, the embodied coexistence was created to build Lasem as the "city of the commons". Here's the focus of this article on social relations between Chinese and Javanese of Lasem societies in the construction of the religious and socio-cultural frame, analyzed by qualitative approach. The data obtained through observation, interview, and study toward relevant document.

\section{Chinese in Lasem; Pecinan, Klenteng, and Cultural Assimila- tion}

The formation of the Chinese community in Indonesia happened through a long historical process. It was begun with the trade relations between the Chinese empires with the kingdoms in Indonesia in the early 5th century AD (Poesponegoro 1993). This trade relation would involve coastal towns which were under the power of the ruling kingdoms at that time. The cities on the north coast of Java island that became a haven and settlement of the earliest Chinese merchants include Tuban, Lasem, Rembang, Jepara, Demak, Semarang, Banten, Jakarta, and others (Joe 2004). In the reign of Ming dynasty which lasted from 1368 to 1643, the Chinese from Yunnan did more travels into areas outside of China, including Indonesia with the intention to do a trade. In the later development of the Ming dynasty, it seeks to include the region of Southeast Asia, including Indonesia, into its protectorate region. One of which has the mandate to lead the fleet to travel to Indonesia was Cheng Ho. Cheng Ho did six times voyage to Java from his seven times voyage to Indonesia.

In general, Chinese people who immigrated to Indonesia, particularly in the northern coast of Java Island, were mostly originated from Fukien/Fujian and Kwang Tung. They consisted 
of various tribes which happened to be Hokkien, Hakka, and Cantonese Teociu. They were expert in many kinds of the domain; in which later would be developed in a new place (Indonesia). Hokkien people were the earliest and most numerous immigrant that came to the country. These people, cultural and tradition-wise, were borne trader. Teociu people which came from rural areas of Swatow in the eastern province of Kwantung have expertise in the field of agriculture, so they widely spread outside of Java. Hakka/Khek people come from areas that were not fertile in the province of Kwang Tung, so they immigrated because of the difficulties of life. Among the Chinese people who immigrated to Indonesia, they were the poorest group. Hakka and Teociu mostly worked in the mining areas in Indonesia such as West Kalimantan, Bangka, Belitung, and Sumatra. The development of big cities like in Java Island like Jakarta and Priangan which opened for the Chinese traders have attracted Hakka and Teociu people to move to West Java (Koentjaraningrat 1980). In development, they spread out and settle in other cities in Java. Cantonese people who were experts in the field of carpentry and industry came to Indonesia with financial capital and skills, so that in a new place they could develop businesses in several fields, such as carpentry, industrial, restaurant, hospitality, and so forth (Tan 2008).

In addition to the tribes mentioned above, there were some parts of Chinese tribes in small amounts such as Ciangcu, Cuanciu, Hokcia, Hai Lu Hong, Hinghua, Hainan, Shanghai, Hunan, Shantung, in small numbers which were scattered in various regions in Indonesia (Gondomono 1996). Java was no exception to become the destination of minority tribe. Kwangsor, Hokchins, and Hokcia were among the earliest minority immigrant to move to Java. These people's specialty was also trading, making their adaptation to the new environment quite smooth. 
Meanwhile, Chinese people moved to Lasem were expected of Zhangzhou origin in Fujian Province. This is due to the similarity shared in the figure being worshipped in the temple as well as the worship procedures that said being alike with the practice in the province (Mutakin 1993).

The arrival of the Chinese people in Lasem was in the XV century (1411-1416) pioneered by Bi Nang Un, envoy of the Ming Dynasty came from the region of Yunnan. Then he set up a Chinese village in Lasem. Only after that, the next wave of the arrival of the Chinese people was dominated by Hokkien who practiced Confucianism. Lasem which time it developed to be a port town, was attractive for the people of China who like to trade. The arrival of the first wave of Chinese citizens was all men. Then they mingled with the natives, got married and had children in Lasem (Annas 2011).

The development of ethnic of Chinese settlement enlarged toward the square of Lasem or central government. This situation constructed the area of trade and regional government merged into unity in the center of town. After 1600 AC, more Chinese immigrated mainly from Fujian province to Lasem due to a great deal of their relatives and colleagues who have inhabited the city. Later on, the development of their communities was widespread towards the southern part of Lasem's central government, even though geographically did not reach the Lasem River. However, the area where they built their settlement was located near to the eastern part of the river and called Karang Turi (Annas 2011).

On development, the Chinese community settlement in Lasem was followed by the construction of the temple as a means to worship and the worship of ancestors, as well as for social and cultural activities.

Chinatown and the temple eventually became two things that cannot be separated in the life of the Chinese community in 
Lasem. Chinatown is the name for the public residential areas with typical Chinese culture and traditions of their home country. The temple is a building for worship and worship gods in religious beliefs Tri Dharma (Taoism-Confucianism-Buddhism). Besides being a place of worship, the klenteng serves as a medium of expression to show the existence of Chinese culture (Handinoto 2004). So, in general, it can be said that in the early formation of Chinatowns (pecinan) of Lasem until today, the identity/image of Chinatown neighborhood are temples which located in the region. Likewise, the location where the temple stood always located around Chinatown.

Klenteng in various Chinatowns in Lasem became a landmark and the identity of the town because the temple was built with the rules and special characteristics that distinguish it from residential buildings of Chinese communities. The building of temples and residential houses in the neighborhood of Chinese community in Lasem refers to the configuration of the surrounding natural environment i.e. the location of mountains, hills, rivers, and plains sloping.

It is difficult to trace the origin of the designation of klenteng for building places of worship of Chinese society. Most researchers say that the name of the klenteng comes from small and large chimes are used as supplies of worship, which reads "klinting-klinting" or "klonteng-klonteng". Some are of the opinion that the temple is derived from the word "Yin Ting" or "Guan Yin Ting”, which means a place of worship Goddess Kwan Im.

There are three temples located adjacent to the river of Lasem namely $\mathrm{Cu}$ An Kiong Temple located at Jalan Dasun 19 Lasem, Gie Yong Bio Temple is located on Jl. Babagan 7 Lasem, and Poo An Bio Temple is located on Jl. Karangturi VII / 13, Lasem. Considering the names of the temples that contain the words Bio and Kiong, it may be mentioned that the existing 
temples in Lasem are temples of Confucianism/Taoism and the clan temple. Temples are also distinguished by the function and purpose of its establishment, namely the common temples and clan temples.

The existence of temple in Lasem did not only reflect the activity of spirituality and the Chinese people's belief in Lasem but also reflect the whole cultural, social, economic and political entity of Chinese community.

Chinese people in Lasem have been engaged in a long interaction with the local communities. This cultural interaction has an influence on the complexity of cultural assimilation and religious syncretism. One of the effects of this cultural assimilation is Batik of Lasem. Flowers and animals become Lasem Batik motifs, such as phoenixes, peacocks, as well as animals in Chinese mythology, the Dragon. These animal and floral motifs had been used by the craftsmen of Lasem Batik hereditary, as stated by Sigit Witjaksono (Njo Tjoen Hian), owner of Sekar Kencana, a Batik factory in Lasem. The ancestors of Sigit are derived from the Hokkien province of China, who moved to Lasem in the 1740's. His Batik business passed on from his father who used to supply batik cloth to Malaysia. Sigit said that the motifs of Lasem Batik are a form of acculturation between China and Java. There are nuances of Chinese motifs and an influence of Batik of Java, but the typical motif could be seen from the red color of chicken blood 'abang getih pithik'.

"We have been always using the typical motifs of China, since the Dutch colonial era, no one knows exactly. The motifs introduced by the Chinese who came to Lasem" (Witjaksono 2015).

According to Sigit, the acculturation of two cultures that occurred since the first constructed Lasem to be a region that is colored with the values of tolerance. Inter-ethnic and religious tolerance in Lasem, according to Sigit, is built by the attitudes 
of Lasem people who respect each other's faith. As Batik craftsmen, Sigit made Batik ornament with the words "Allahu Akbar" and "Muhammad". When the normal process of shedding wax is done by foot, the ornament was created by hand. This fabric wall ornament is now displayed on an Islamic boarding school's wall, namely Pondok Pesantren "Kauman" which located in midst of Chinatown.

"There is nothing that distinguishes Chinese and Javanese, the example I have been married more than 50 years with my wife Marpat Javanese descent, and our children also have a different religion, but there was never any clashes and conflicts" said Sigit Witjaksono (2015).

The other acculturation took form as music commonly called Pethet Lasem, whose formation was quite unique. Long ago, Mpu Wardapa, in collaboration with the preacher of Islam Waliyullah Makdum Ibrahim (known as Sunan Bonang) composed a gamelan based music rhythm that later would be known among the locals as Pathet Lasem, Suluk Lasem, and Sampak Lasem. These are presented in every event of Wayang Kulit in Lasem. In Babad Lasem, one of Bi Nang Un's Childs whose name was Bi Nang $\mathrm{Na}$ which was later renamed as Mpu Wardapa became one of the pioneers of the musical arts of karawitan and gamelan in Lasem.

Thus, it is not surprisingly when observing on gending of Lasem will obviously get the feel of acculturation between Javanese and Chinese cultures, said Slamet Wijaya, one observer of Lasem history, a former employee of the Department of Education of Rembang (Wijaya 2014).

Besides Batik and Pathek of Lasem, the impact of the interaction in the form of cultural assimilation and acculturation also could be known well from the phenomenon that the Chinese people in Lasem are divided into two groups, namely Totok Chinese and peranakan Chinese (Kristianto 2012). 
Totok Chinese is a full-blooded native Chinese who came to Indonesia from the beginning. They are married to women from his country. They had not yet adapted to the local culture. Their traditions and customs are still adapted from their origin of country. Peranakan Chinese are born from marriages between Chinese people (usually male) with locals (Javanese). They've been doing customs and local traditions and mastering the local language well and getting an education in public schools. While Totok Chinese has been studying in Chinese schools were established specifically to educate the Chinese people with the Chinese education model.

Totok Chinese, who was immigrants from China since the beginning, has been living in the urban area in a group of home series which is also used as a place of business. They still follow the pattern of society and the family system which was rooted in their home country called as a patrilineal system. Confucianism and Taoism strictly implemented to regulate family relationships and social relations.

While peranakan Chinese is a moderate Chinese people, because they have made an interaction with a more heterogeneous society openly, and many of those who have been studying in the same schools of Javanese. Democratic attitude is very prominent in the family of peranakan Chinese. There is no strict division of the tasks that must be dealt with male or female. Male (father) can perform domestic chores which include household tasks and women (mothers) can perform tasks outside the home. More preferably life orientation in the family is harmony.

Generally, the difference between the Totok and the peranakan Chinese was not so significant around this time for the indigenous Chinese have been settled in Lasem for many centuries. Their culture has already assimilated into the local community (Javanese), thus their lives were no longer exclusive. 
The Chinese people in Lasem are almost similar to the indigenous people (Javanese) right now, both physically and in terms of its culture that it is difficult to distinguish between the Chinese and Javanese. Even converts Chinese (the Chinese who converted to Islam) and Muslim, do their beliefs and customs which are the same as the natives so that assimilation with the native residents is progressing well without leaving their Chinese culture.

As spoken by Ahmad Yafi'uddin, a student of Islamic boarding school (santri) who lives in Chinatown, there are many Chinese men in Lasem who are able to perform religious practices in the way the Muslims do, such as reading tablilan and yasinan when one of the residents died. They could read Arabic from following Lasem festival frequently in which tablil is one the agenda in every praying event there. Moreover, a Confucianist of peranakan Chinese occasionally asked the kyai or santri to perform tablilan after the burial of a deceased relative (Yafi'uddin 2014). This was a kind of religious syncretism based on social interaction.

\section{Cultural Dialogue, Santri, Pesantren, and Inclusive Social Inter- action}

Javanese community in Lasem is mostly Muslims who are affiliated with pesantren. It is very visible in everyday life of the Lasem society, in which the tradition of pesantren namely sarung and peci/songkok are identical symbols attached to it. Both identical symbols will be very easy to be encountered in everyday sights in Lasem's daily life, such as in the square, markets, shops, streets and other places. Many people are seemed to paced and wearing those typical uniform of pesantren. Not only the students who are in the middle of learning activity as everybody seemed to be wearing a pecilsongkok. This kind of 
view can be seen throughout the day, not only at the time of the five daily prayers. They use such uniform in a variety of social interactions openly. I did observation in less than five years in a separate time, 2011 to 2015.

That is why it is correct that Lasem, besides known as the "small China town", also known as the "santri town". The reason is also a relic of pesantren in this town that we can track records until now (Ma'shoem and Ma'shoem 2012). Many charismatic ulama' died in this town. For example, Sayid Abdurrahman Basyaiban (Mbah Sambu) whose tomb has the architectural form of the building sort of Chinese tradition.

According to Islamic clerics in Lasem who I have met, Mbah Sambu was the first spreader figures of Islam in Lasem. The majority of the founders and leaders of pesantren in Lasem are his offspring. The fourth president of Indonesia; Abdurrahman Wahid is one of the great-grandson of Mbah Sambu. Mbah Sambu's influence on Islamic world was throughout Java. His era was marked by the construction of a mosque in the center town of Lasem, exactly in front of the square of Lasem in 1588.

Tomb of Mbah Sambu is used as a symbol of linkage between two traditions in the framework of pluralism: Islam and Confucianism-Chinese. Because the architecture of this tomb is Chinese picturing, but the figure which was buried in is Muslim figure. For this, some Chinese people in Lasem stated that Mbah Sambu was a Chinese. The actual name of Mbah Sambu was Sam Ho, because the name is difficult to pronounce by tongues of Javanese so it became Sambu, and also because in this his tomb there is also his wife's body in the same grave. Husband and wife buried in one grave are a Chinese funeral tradition. However, for Muslims in Lasem, the condition was one example of Mbah Sambu's wisdom in addressing religious and ethnic plurality in Lasem. Their faith said that Mbah Sambu actually is 
a descendant of the Prophet Muhammad saw. who came from Yemen.

Most tombs of Muslim public figures of Lasem can be found in the north of Jami' Mosque of Lasem, such as KH. Baidhowi, KH. Khalil, KH. Ma'shoem, KH. Masduki, and others. So, it is not excessive if Lasem nicknamed as the "santri town", considering the number of leading Islamic scholars 'kyai', boarding school 'pesantren', Islamic studies based curriculum school 'madrasah', the number of madrassah diniyyah and regular schools in Lasem based on the grade are 33 kindergartens and raudlatul athfāl, 35 elementary schools and Islamic elementary schools, 10 junior high schools and madrasah thanawiyyah, 5 high school and madrasah 'aliyyah, and 4 SMK, and the thousands number of santri who studied Islam in this town.

The big number of indigenous people (Javanese) of Lasem studied about pesantren. They generally take a formal school (elementary, middle, high school/vocational) from morning to noon, then from noon until the afternoon studying Islamic religion by classical models (ibtida'iyyah, thānawiyyah, and 'aliyyah) in madrasah of pesantren. Later that night, the students are required to follow the teachings of classical texts (kitab kuning) with bandongan teaching methods in the mosques.

The presence of pesantren in the middle Lasem society, in which Chinese community also exists, brings a very positive impact for the people, mainly in the form of social community. It is all thanks to the dedication of pesantren (comprised of religious scholars and the students) toward society and its surroundings.

${ }^{2}$ List of Pondok Pesantren (PP) in Lasem i.e. PP. Al-Fakhriyyah, PP. AlHadi, PP. Al-Hamidiyah, PP. Al-Hidayat, PP. Al-Hidayat Al-Quraniyyah, PP. Al-Hidayat Ash-Syakriyyah, PP. Al-Ishlah, PP. Al-Mas'udiy, PP. Al-Muyassar, PP. Al-Hidayat Al-Ma'shudi, PP. An-Nur, PP. An-Nuriyyah, PP. Ash-Sholatiyyah, PP. At-Taslim, PP. Kauman, PP. MTI Al-Aziz, PP. MTI Al-Fath, PP. Nailunnajah, PP. Roudlotut Thullab, and PP. Wahdatuth Thullab Al-Wahda) 
In this case, based on data obtained through interviews with Yafi'uddin, one senior student of pesantren in pecinan area of Lasem, that among the social activities undertaken by the students as directed by the kyai include community service in the form of cleaning up the environment, being a night guard with Chinese citizens, participate in cultural activities, and perform prayer for the deceased resident (Yafi'uddin 2014).

The students' community service is usually done in accordance with the citizen's. If there are people carrying out social work, the students will tag along even though there was no notification in advance. Yet often people will notify the santri if non-regular community service is about to be held. As for the night watch activity, the students are working together with the residents hand in hand regularly. It is routinely carried out in the village guard post and also around pesantren. Meanwhile for students to participate in cultural activities, the community provides a lot of events and festivals in which the students can take part in, for example in the Carnaval of Barongsai during a particular occasion such as Lasem Festival. The Sanggar Barongsai (a board of lion organization) in Lasem is one of the biggest Sanggar Barongsai in Java. It is unique that leaders of this sanggar or organization are precisely not only the Chinese, but also the native (Javanese-santri). Its manager and staff were consisting of Chinese and santri. Whereas, in order to mourn the corpse of the Chinese, the students usually being assisted by the kyai. The students also help the family of the deceased such as preparing camp, cleaning up the house, and many others. Some of these social activities which undertaken by pesantren in Lasem sociologically forming the pattern of relationships between pesantren and Chinese people.

Based on research data obtained from interviews with Kristianto (Ie Keng Haow), the head of RT 02 RW 02, Karangturi 
(a Chinese 'pecinan' village), he stated that the presence of pesantren is very beneficial for the Chinese society who are the predominant citizen of the village, and no citizen of the village who reject and resent the presence of the pesantren. This is because the ethics of social interaction presented by kyai and santri are very good and does not discriminate against race or belief, as it also the kyai and santri participate in every social activity. Even, to honor our ethnic and belief (Chinese-Confucianism), the pesantren build a temple-like architecture for guard post function which was made not far from the building of pesantren. During its development, this guard post that painted with bright red color (color typical of China), becomes a boarding place to interact and dialog between pesantren and Chinese. Even pesantren also do not mind when Chinese-Confucianism adherent gave a light lantern to be installed in front of the pesantren. The Chinese also attend the pesantren when held Islamic events, and during eid al-fitr, the religious scholars or kyai and santri would do a home visit to greet the Chinese. Conversely, when the Chinese celebrated their feast, kyai and santri will be together invited for meals (Kristianto 2012).

In addition to the substation, social interaction between Muslim of pesantren and Chinese-Confucianism can be found in coffee shops. In Lasem, the coffee shop cafe is in huge numbers. Its existence is as an alternative communication place across traditions and religions without suspicion mutually strengthening the cultural relationship of between residents of Lasem, especially Javanese-Muslim and Chinese-Confucianism. Here, every morning, the Chinese and Javanese get breakfast, drinking coffee and discussing anything together, ranging from a score of a football game, the celebration of carnival culture, politics of homeland, to the preparation of events in pesantren and feast day celebration of the Chinese citizens. 


\section{Factors Contributing to Eliminate Inter-Ethnic Conflict and}

\section{Building Coexistence and Tolerance in Lasem}

The factors that affect basically to the peaceful coexistence and mutual tolerance on social relationships between santri (indigenous communities or Javanese-Muslim) with Chinese (Confucianism) in Lasem, based on the results of this study through observation, interviews, and historical literature review, are as follows:

Firstly, the persistence of the Chinese community in Lasem and also the root of pesantren in the town which have been established long enough has supported the occurrence of primordial historical ties that link them.

Secondly, most Chinese people are married to JavaneseMuslim or santri which ultimately became affiliated with the pesantren-based Muslim. Then, it made a strong cultural assimilation.

Thirdly, there is a sense of belonging to the culture of Lasem which built by the Muslim figures and Chinese in history that they recalled. Hence the santri communities have great respect for the culture of Chinese in Lasem and vice versa. This fact shows the same flavor that has implications for how to preserve and care for the culture and traditions together.

Fourth, various cultural forums (e.g. Gardu/village post guard and coffee shops, and etc) that bring santri with Chinese communities together are a good model of effective dialogue in the realization of harmonious life. Thus, these people are not easily ignited by conflict. Further, this strengthens the coexistence and tolerance among them.

Fifth, education is also a major factor in the social life coexistence that existed between santri with Chinese communities in Lasem. The Chinese community has thought to study together with santri. This togetherness of the process of learning contrib- 
uted into and developed the spirit of tolerance and coexistence frameworks from the early age to the adulthood among them.

Sixth, the coexistence and tolerance which is built between santri with Chinese in Lasem also cannot be separated from the distribution of capital. Capital is a device to efficiently utilize resources and a source of strength. Javanese-Muslim uses symbolic capital in the form of charisma and cultural capital in the form of a religious follower and religious knowledge as legitimacy in establishing social relations. It was formed through the breadth of networking of pesantren by santri communities in Lasem, which has been established for about 150 years. Chinese people use the economic capital to enforce its presence in santri environment. While social capital becomes the primary adhesive, this is shown in cross-group communication that exists between individuals. This capital deployment of symbolic, social, cultural, and economic enables the achievement of a peace agreement which affects the preservation of harmonious relations between santri with Chinese in the form of embodied coexistence and tolerance as the realization of pluralism.

\section{Concluding Remark}

The long history of the relationship between santri and Chinese community existence in Lasem provides color and uniqueness of religious civilization (form and structure) of Lasem, both physical and non-physical. Similarly, acculturation of both has given color to the cultural and community activities in Lasem. The dynamics of religious, social, and cultural life of santri and Chinese communities in Lasem leave a trail of beautiful tolerance and coexistence in Indonesia. Patterns of social relationships they have been doing become Lasem's characteristics, which makes them resistant to ethnic and religious conflicts, unlike what had been experienced by other cities and towns in In- 
donesia. It could be a role model for us to embodying pluralism between Muslim and Chinese in the term of attitudes toward plural societies in nowadays.

\section{Bibliography}

Annas, Saiful. 2011. "Muslim Membaur Di China Kecil.” Suara Merdeka, August edition.

Bertrand, Jacques. 2004. Nationalism and Ethnic Conflict in Indonesia. Cambridge: Cambridge University Press.

Gondomono. 1996. Membanting Tulang Menyembah Arwah: Kehidupan Kekotaan Masyarakat Cina. Jakarta: Fakultas Sastra, Universitas Indonesia.

Habib, Achmad. 2004. Konflik Antar Etnik di Pedesaan: Pasang Surut Hubungan Cina-Jawa. Yogyakarta: LKiS Pelangi Aksara.

Hamzah, Alfian. 1998. Kapok Jadi Nonpri: Warga Tionghoa Mencari Keadilan. Jakarta: Zaman.

Handinoto. 2004. "Lingkungan Pecinan Dalam Tata Ruang Kota Di Jawa Pada Masa Kolonial.” DIMENSI (Journal of Architecture and Built Environment) 27 (1). doi:10.9744/ dimensi.27.1.

Joe, Liem Thian. 2004. Riwayat Semarang. Yogyakarta: Hasta Wahana.

Koentjaraningrat. 1980. Manusia dan Kebudayaan di Indonesia. Jakarta: Djambatan.

Kristianto, Ie Keng Haow. 2012. "Chairman of RT 02 RW 02 Karangturi Village, Lasem, Rembang.”

Ma'shoem, KH. Syihab, and KH. Zaim Ahmad Ma'shoem. 2012. "Grandsons of KH. Ahmad Ma'shoem.” August.

Mutakin, Hidayat Zenal. 1993. Masyarakat dan Kebudayaan Cina Indonesia. Bandung: Tarsito. 
Poesponegoro, Notosusanto. 1993. Sejarah Nasional Indonesia. Vol. III. Jakarta: Departemen Pendidikan dan Kebudayaan, Direktorat Sejarah dan Nilai Tradisional, Proyek Inventarisasi dan Dokumentasi Sejarah Nasional.

Saleh, Hasan, Anzis Kleden, and Ignas Bethan. 1992. Mengapa Aceh Bergolak : Bertarung Untuk Kepentingan Bangsa Dan Bersabung Untuk Kepentingan Daerah. Jakarta: Pustaka Utama Grafiti.

Shekhar, Vibhanshu. 2011. The Politics of Islam, Nation-Building and Development: Ethnic Violence and Terrorism in Indonesia. New Delhi: Anamika Publishers \& Distributors.

Susan, Novri. 2009. Sosiologi Konflik Dan Isu-Isu Konflik Kontemporer. Jakarta: Kencana Prenada Media.

Tan, Mely G. 2008. Etnis Tionghoa Di Indonesia: Kumpulan Tulisan. Jakarta: Yayasan Obor Indonesia.

Wijaya, Slamet. 2014. "Former Employee of the Department of Education of Rembang.”

Winarini, Retno, and Bambang Samsu Badriyanto. 2012. "Kerusuhan Anti-Cina Di Kabupaten Situbondo Tahun 1967." Mozaik : Jurnal Ilmu Humaniora 12 (2): 141-56.

Witjaksono, Njo Tjoen Hian Sigit. 2015. “Owner of Sekar Kencana, Batik Factory in Lasem.” February.

Yafi'uddin, Ahmad. 2014. "Chairman of Santri Organization at Pesantren Kauman Karangturi Lasem.” June. 